\title{
Not everything helps the same for everyone: relevance of extracurricular activities for academic achievement
}

\author{
Álvaro Balaguer (iD ${ }^{1 凶}$, Edgar Benítez (iD ${ }^{2}$, Aranzazu Albertos (i] ${ }^{1}$ \& Sonia Lara ${ }^{1}$
}

Participation in organized Extracurricular Activities has contributed to improve academic achievement. However, this does not happen in the same way; it depends on sex, age, or parental educational level. Our objective is to know the importance of these factor interactions' in the explanation of academic achievement. The sample consisted of 1148 adolescents, aged between 12 and 18 years, 52\% of whom were female. Participants completed the Extracurricular Activities questionnaire, and academic and sociodemographic data were collected. The results show that differences in academic achievement depend on the adolescent stage. In early adolescence, girls improve in academic achievement, as well as with better parental education, reading of books and activity duration. On the contrary, in the middle and late adolescence, academic achievement improves with not participating in collective sports and reduced activity breadth, although parental educational level follows the same trend as in the early adolescence. These results reinforce the evolutionary hypothesis of specialization in the choice of activities throughout adolescence. In this sense, some proposals for schools that advocate for greater integration of curricular and non-curricular elements are discussed.

\footnotetext{
${ }^{1}$ School of Education and Psychology, University of Navarre, Pamplona, Spain. ${ }^{2}$ Institute of Data Science and Artificial Intelligence, University of Navarre, Pamplona, Spain. ${ }^{凶}$ email: abalaguer@unav.es
} 


\section{Introduction}

- he class "extracurricular activities" (EA) constitutes a positive youth developmental asset (Durlak et al., 2010; Eccles and Gootman, 2002; Eisman et al., 2016; Farb and Matjasko, 2012; Mueller et al., 2011) and covers a broad range of categories that share some essential elements (Hansen et al., 2010). Indeed, competent adults supervise these activities, which often involve peer interaction. They also have regular attendance schedules, offer practical learning opportunities and enable young people to spend time engaged in their own interests (Hansen and Larson, 2007).

EA does not form part of the school curriculum and, unlike formal education, student participation is voluntary. Adolescents often develop meaningful relationships with their peers and their instructors. This fact creates an appropriate context in which to develop identity, initiative, and social skills (Hirsch et al., 2011; Larson et al., 2006). These aspects help in theorizing about organized activities and contribute to different processes of adolescent development.

Moreover, investigations of the types of activities that involve youth in their free time have identify the relevant components that promote positive development in supervised/structured environments or, specifically, in extracurricular programs or activities. Positive youth development programs incorporate manifold elements that promote such development, with importance directed toward adult-adolescent relationships that tend to involve young people over time (Roth et al., 1998).

Type of activity. Studies of different types of EA address various development experiences (Eccles and Gootman, 2002), such as sports, performing arts, service clubs, and faith-based youth groups (Vandell et al., 2015). Research shows differences between sports and artistic EA, based on the results they promote in youth (Hansen et al., 2003; Im et al., 2016). Thus, evidence shows that artistic activities improve adolescent adjustment, as well as the participants' self-knowledge, self-discipline, and artistic talents (Hansen et al., 2003).

Sports EA not only prevent risk behaviors, but also improve the social and academic abilities of youth (Darling, 2005). However, collective sports contribute to a lower level of academic, social, or preventive skills promotion than other types of EA (Hansen et al., 2010; Wilson et al., 2010).

Bartko and Eccles (2003) classify adolescents very involved in sports, spending more time with friends, and performing other EA in different groups, with high participation rates in school clubs, tasks, and reading for pleasure. For Im et al. (2016), participation in sports and artistic activities predicts an increase of self-efficacy in academic competence, so EA provides a context in which students can face and overcome challenges and increase the level of their skill, thus building trust.

Based on the approach of Mahoney et al. (2005), Reading books for pleasure would not be an organized extracurricular activity. In fact,

"these activities are generally voluntary, have regular and scheduled meetings, maintain developmentally based expectations and rules for participants in the activity setting (and sometimes beyond it), involve several participants, offer supervision and guidance from adults, and are organized around developing particular skills and achieving goals" (Mahoney et al., 2005, p. 4).

Nonetheless, Reading books it is very relevant for youth development, relating to greater participation in a wider breadth of activities, as well as greater engagement in both extracurricular and curricular tasks (Bartko and Eccles, 2003).
Activity engagement. For EA to function as more effective assets requires youth engagement (Weiss et al., 2005) though factors such as breadth, intensity and duration (Bohnert et al., 2010; Busseri and Rose-Krasnor, 2009; Busseri et al., 2006). The benefits of participation in EA, both in the curricular field and in the personal development of the young person, depend on the characteristics of their participation experience. In turn, such experiences depend on their engagement, whether psychological (e.g. duration) or behavioral (e.g. breadth, intensity). However, a consensus on the conceptualization of participation should specify the aspects of behavioral and psychological engagement (Eisman et al., 2016).

Breadth of activities. Breadth refers to the number of EA that involve youth. The study of Breadth provides a broad description of the range of student skills and interests (Bohnert et al., 2010; Busseri and Rose-Krasnor, 2009; Busseri et al., 2006; Linver et al., 2009).

The range of activities refers to the participation in different activities in a certain period and may refer to the total number of activities in which a young person engages (Busseri and RoseKrasnor, 2009) or the total number of different types of activities (Eccles and Barber, 1999). Contrary to participation in a single activity, a wide range of participation allows young people greater diversity of learning experiences, supportive interactions with adults, and broad networks of peers (Bohnert et al., 2010; Eccles and Barber, 1999; Vandell et al., 2015).

Duration of activities. The duration or consistency of participation in EA refers to the maintenance over time. "Dosage has been conceptualized in terms of consistency and continuity over time, measured as the proportion of periods in which youth engage in activities" (Pierce et al., 2013; in Vandell et al., 2015).

Longitudinal studies have measured consistency of participation among both elementary and middle-school children (see National Institute of Child Health and Human Development Early Child Care Research Network, 2004; Pierce et al., 2013) and in adolescents (see Mahoney et al., 2003; Zaff et al., 2003). The participation in EA over the years could increase the benefits for youth development, as a result of greater exposure to such opportunities (Eisman et al., 2016; Tudge et al., 2009).

\section{Differences in adolescents' activity participation}

Sex differences in adolescents' activity participation. Sex relates to participation in EA, with girls showing more behavioral engagement in EA except in sports (Denault and Poulin, 2009b; Eccles et al., 2003; Kleiner et al., 2004). Indeed, boys are more likely than girls to participate in sports, while girls are more likely than boys to participate in classes and clubs (Kleiner et al., 2004) or artistic EA (Luthar et al., 2006). The impact of EA on positive development is higher for boys (Pierce et al., 2010; Urban et al., 2009). No evidence indicates differences in participation according to sex, rather than age (Eisman et al., 2016). In any case, evidence of gender-related differences in the effects of EA is scarce.

Regarding risk behaviors, according to Eccles et al. (2003), participation in a competition sports team in late adolescence for both sexes is associated with higher alcohol consumption, the opposite of participation in artistic activities.

Stage differences in adolescents' activity participation. Eisman et al. (2016) argue that the stage of development of the young person determines the importance of each type of engagement. In early adolescence, people tend to participate in a wider range of EA. Indeed, the breadth of participation could be more relevant in 
early adolescence than in late adolescence, because exploring different interests and strengthening bonds with peers characterizes early adolescence (Bohnert et al., 2010; Busseri and Rose-Krasnor, 2009). Also, as mentioned, the breadth of participation enables more learning opportunities and broader networks with different groups of peers and supportive adults (Vandell et al., 2015).

The young persons' persistence in an activity depends on different factors, such as the activity itself, personal characteristics, and interests, and other environmental aspects, such as family circumstances, peers, and school or community characteristics (Vandell et al., 2015). Accordingly, as progress is made in developmental stages, adolescents develop greater control over their use of time (Fredricks and Eccles, 2010) and refine their personal interests. Consequently, in middle-to-late adolescence, young people participate in fewer activities, but with more intensity (Busseri et al., 2006; Denault and Poulin, 2009a) and interest.

Indeed, leaving a type of activity may reflect the progression of development. Thereby, young people begin testing different EA, then focus on a smaller number of them as their interests become more defined (Badura et al., 2016; Rose-Krasnor et al., 2006), ranging from participating in a wide range of activities to a small number over time (Denault and Poulin, 2009a; Eccles and Barber, 1999; Rose-Krasnor et al., 2006). In fact, participation in EA cannot change throughout adolescence (Eisman et al., 2016; Zaff et al., 2003) or change constantly along this stage (Farb and Matjasko, 2012), despite disagreements about whether such participation increases (Mahoney et al., 2003) or decreases (Denault and Poulin, 2009b).

Parental education level differences in adolescents' activity participation. Taking account of the context in which young people live is essential to understand the characteristics of their participation in EA. Research on differences in participation have been focus more in terms of socioeconomic factors (Luthar et al., 2006; Pedersen, 2005; Quinn, 1999; Vandell et al., 2015) than in differences related to parental education (Kingdon et al., 2017).

Parental education level is associated with participation in EA, in that youth whose parents have a higher educational level tend to participate more in activities than those whose parents have lower educational levels (Bartko and Eccles, 2003; Eisman et al., 2016; Feldman and Matjasko, 2007; Linver et al., 2009; Vandell et al., 2015), and parental education level also predicts their children's duration in activities (Eisman et al., 2016).

EA associations with academic achievement. The relationship between participation in EA and improvements in academic achievement have been extensively studied. How adolescents decide to manage their free time is a protective factor related to academic achievement in higher grades, as well as to recovering from low GPAs (Eccles et al., 2003; Linver et al., 2009; Peck et al., 2008; Roth et al., 2010).

Participation in EA also relates to furthering the adolescent's permanence in the educational system by improving their behavior and school attendance (Simpkins et al., 2004). Participation in EA improves other relevant aspects of curricular success, such as lower school dropout rates (Mahoney, 2000) and the school climate, in terms of associations with friendship and prosocial behavior with peers, as well as less aggressive behavior toward them (Eccles and Templeton, 2002).

Participants in sports activities experience lower academic achievement than those who participate in artistic activities (Eccles et al., 2003). Reading books is a protective factor in preventing school failure, and it improves academic achievement in early (Kingdon et al., 2017) and late adolescence (e.g. Horbec, 2012; Whitten et al., 2019). Adolescents reading books during their extracurricular schedule has been related to higher academic aspirations (McGaha and Fitzpatrick, 2010). Conversely, lack of reading has been related to difficulties in the transition to college (Rubin, 2008).

Most of the research that associating EA with academic achievement shows the latter as an outcome that participation improves (Eisman et al., 2016; Linver et al., 2009). Although both breadth and duration have been related to academic achievement (Palma et al., 2014), behavioral engagement (i.e. breadth) shows more predictive ability (Barber et al., 2005; Eisman et al., 2016; Fredricks and Eccles, 2006). However, duration-evaluated as consistent participation in a wide range of EA-has also predicted higher grades and academic achievement in studies that control for sex and parental education (Darling et al., 2005; Zaff et al., 2003).

The traditional controversy over whether breadth contributes to improving academic achievement (Linver et al., 2009) has given way to recent findings that indicate the relation of breadth to improvement in early adolescence (Eisman et al., 2016; Roth et al., 2010). However, the same would not happen in late adolescence, when duration is the more consistent predictor (Eisman et al., 2016).

Regarding the relationship between participation in EA and academic achievement in terms of sex and age, younger girls show the highest academic achievement (Kingdon et al., 2017; OECD, 2015), depending on the type of activity. For instance, an association has been found between reading books and academic achievement in early adolescence (i.e., schoolchildren between 12 and 14 years old) (Kingdon et al., 2017).

Aims and hypothesis. Despite the abundant literature on the effects of different EA on academic performance, empirical evidence is lacking for the relationship between extracurricular variables, such as breadth and duration, and academic achievement in Hispanic (including Spanish) contexts. Therefore, we aimed to investigate in such a context two groups of noncurricular factors-EA and sociodemographic variables-and a key curricular variable, academic achievement. In particular, we consider sex, age (distinguishing between early middle and late adolescence) and parental education level as sociodemographic variables.

On the other hand, as variables of EA, we take into account the breadth-understood as Busseri and Rose-Krasnor (2009) state it - and duration of participation, the type of activity (i.e., individual sport, collective sport and arts), and add an informal activity traditionally related to academic achievement, the reading of books. Associations of EA and sociodemographic variables with academic achievement were analized.

The hypotheses of the investigation are:

1. Types of activities (i.e., reading of books, artistic, and individual or collective sports) are associated with academic achievement, controlling for sex, age, and parental education level.

2. Duration of EA is associated with academic achievement, controlling for sex, age, and parental education level.

3. Breadth of EA is associated with academic achievement, controlling for sex, age, and parental education level.

\section{Method}

Participants. Participants were recruited at 10 schools randomly selected from among all secondary schools in the province of Zaragoza, in Spain. We requested participation from students in 


\begin{tabular}{|c|c|c|}
\hline Characteristic & $\begin{array}{l}\text { Boys } \\
N=549 \\
(\%)\end{array}$ & $\begin{array}{l}\text { Girls } \\
\mathbf{N}=\mathbf{5 9 9} \\
(\%)\end{array}$ \\
\hline \multicolumn{3}{|l|}{ Age group } \\
\hline 12-14 у.о. & 64.5 & 63.3 \\
\hline 15-18 у.о. & 35.5 & 36.7 \\
\hline \multicolumn{3}{|c|}{ Parental education levela } \\
\hline Low & 32.8 & 32.5 \\
\hline Middle & 27.6 & 26.8 \\
\hline High & 39.6 & 40.7 \\
\hline \multicolumn{3}{|c|}{ Individual sports activities } \\
\hline No & 71.0 & 66.8 \\
\hline Yes & 29.0 & 33.2 \\
\hline \multicolumn{3}{|c|}{ Collective sports activities } \\
\hline No & 34.2 & 59.3 \\
\hline Yes & 65.8 & 40.7 \\
\hline \multicolumn{3}{|c|}{ Artistic activities } \\
\hline No & 73.0 & 58.1 \\
\hline Yes & 27.0 & 41.9 \\
\hline \multicolumn{3}{|l|}{ Reading books } \\
\hline No & 89.0 & 86.5 \\
\hline Yes & 11.0 & 13.5 \\
\hline \multicolumn{3}{|l|}{ Breadth of EA } \\
\hline Low & 16.9 & 30.1 \\
\hline Middle & 44.1 & 22.2 \\
\hline High & 39.0 & 47.7 \\
\hline \multicolumn{3}{|l|}{ Duration of EA } \\
\hline Low & 38.4 & 40.7 \\
\hline Middle & 30.8 & 29.1 \\
\hline High & 30.8 & 30.2 \\
\hline \multicolumn{3}{|c|}{ Academic achievement } \\
\hline Deficient & 29.6 & 26.3 \\
\hline Sufficient & 35.5 & 27.0 \\
\hline Superior & 34.9 & 46.7 \\
\hline
\end{tabular}

grades 7, 9, and 11 (around 12, 14, and 16 years old, respectively). In total, 1148 students completed the survey, with balanced distributions by sex $(50.2 \%$ female) and age (distribution of ages can be found in Table 1).

Instruments. $E A$ (Hermoso et al., 2010) contains descriptive data about performing organized activities after school hours. From among adolescents who participated in such organized activities, data for a series of dummy variables were collected, covering the number of courses underway, the type of activity (sports and/or arts), and other items related to students' perceptions of participation. Experts assessed and critiqued the questionnaire, and it fulfilled the requirements of external, internal, and content validity.

Sociodemographic variables data on sex, age, and parental education level were collected.

Academic achievement attends to a self-report of the previous course GPA.

Procedure. This study was carried out in accordance with the recommendations of the Council of the British Educational Research Association in its second edition of the Ethical Guidelines for Educational Research (2011). Subjects received no compensation for participating in the study. Compliance with these ethical standards was guaranteed at all time.

The objectives and characteristics of the study were explained to the principals and counselors, who agreed to participate.
Afterwards, they transferred the study objectives and questionnaires to the tutors from the different groups. Prior to completion, families were informed by a letter of the purpose of the study and procedure, and participants' anonymity was ensured. In the same letter, the volunteers were informed of participation and the possibility of excluding from the activity those children whose families did not consent to participation, given that the data was collected during class time.

Data analyses. The age of the participants was dichotomized at the median, which resulted in one group between 12 and 14 years of age and the other between 15 and 18 years of age. For the evaluation of parental education level, three categories were considered: primary basic studies, middle studies, and university studies. The participant was assigned to one according to the highest level either parent had reached. For sports activities, participants were asked if the child was currently involved in individual or collective sports activities.

For the identification of artistic activities, if they were currently participating in dance, theater, music, or plastic-arts activities, any positive response on any of these activities was considered an affirmative response for this type of activity in its entirety. Also, they were asked directly if they were currently dedicating their time to reading books. The time devoted to EA was determined by asking the respondents to report during how many courses they had carried out these activities.

Finally, regarding the breadth of EA, the definition of Busseri and Rose-Krasnor (2009) was adopted, which proposes breadth as the total number of activities in which a young person engages. The response variable related to academic achievement was obtained by asking for the final grade in the immediately preceding course, reported on a scale from 1 to 8 . However, for the descriptive analysis, this variable was categorized as "deficient" (below minimum approval level), "sufficient" (between minimum approval level and up to 5 units), or outstanding (higher than 5 units).

For the evaluation of the proposed hypotheses, a multilevel model of main effects was evaluated, where covariates and evaluation factors were taken as fixed effects, and the school to which the student belonged was categorized as a random effect. The estimation method was through restricted maximum likelihood with the Satterthwaite method for calculating the degrees of freedom. The residuals of the model were evaluated for their normality by means of skewness and kurtosis criteria. A significance value of $p<0.05$ was used. For post hoc comparisons, $t$-tests protected by Fisher were used in cases where the factor had more than two levels; for the rest of the cases, the F-test was considered sufficient. Due to the differential effect of the age of the respondents on the confounding and response variables, the proposed model was estimated independently for each age group.

\section{Results}

In total, $549(47.8 \%)$ males and 599 (52.2\%) females were recruited, a greater proportion of whom were 12-14 years of age, with parents who had a high educational level (see Table 1). Regarding the response variable "academic achievement", the three categories presented show a similar distribution; however, girls show better achievement than boys by more than 10 percentage points in the superior category.

The analysis of variance (Anova) of the multilevel model, proposed for the evaluation of academic achievement as a dependent variable, shows that the responses related to the evaluated variables corroborate the differentiated behavior by age group. For the younger group (12-14 years old), sex, reading books, and duration of EA are significant factors associated with 


\begin{tabular}{|c|c|c|c|c|}
\hline \multirow[t]{2}{*}{ Effect } & \multicolumn{2}{|c|}{ 12-14 y.o. } & \multicolumn{2}{|c|}{ 15-18 y.o. } \\
\hline & $F$ value & $\operatorname{Pr}>F$ & $F$ value & $\operatorname{Pr}>\boldsymbol{F}$ \\
\hline Sex & 6.06 & $0.014^{\star}$ & 1.30 & 0.255 \\
\hline Parental education level & 3.96 & $0.020^{\star}$ & 3.92 & $0.021^{\star}$ \\
\hline Individual sports activities & 0.21 & 0.647 & 3.65 & 0.057 \\
\hline Collective sports activities & 0.19 & 0.666 & 9.18 & $0.003^{\star}$ \\
\hline Artistic activities & 0.03 & 0.866 & 2.31 & 0.129 \\
\hline Reading books & 4.57 & $0.033^{*}$ & 0.65 & 0.420 \\
\hline Breadth of EA & 0.40 & 0.673 & 4.26 & $0.015^{\star}$ \\
\hline Duration of EA & 11.42 & $<0.001^{\star}$ & 1.08 & 0.342 \\
\hline
\end{tabular}

academic achievement, contrary to the results for the older group (15-18 years old) for whom collective sports activities and breadth of EA was significantly related to academic achievement. Only parental education level presented a similar effect for both age groups (Table 2).

The analysis of means showed that for the sex-related factor, between 12 and 14 years of age, the girls had better academic achievement (see Table 3 and Fig. 1a). For the level of education of the parents, those young people whose parents only reported levels of primary education showed the lowest academic achievement, compared to those with both medium levels and high levels of parental education. Regarding collective sports activities, the practice of these activities by the older students affected positively to academic achievement, as Fig. 1b shows. On the contrary, the effect of reading books was found among the younger ones as a promoting factor of academic achievement, also shown in Fig. 1b. Finally, for the variables of time and breadth, a differential in behavior was found again. For the younger students, the time spent most affected their academic achievement, by increasing it. For the older students, breadth was a predictor of academic achievement-in this case, the low level of dispersion is the weaker association, compared to the medium and high levels that present the best values (see Fig. 1c).

\section{Discussion}

The main contribution of this paper is the study of these characteristics in Hispanic, concretely, Spanish contexts, which is not very common in the scientific literature. Our results indicate that adolescents' choices of EA participation are associated with academic achievement, as other investigations have shown (Badura et al., 2016; Bartko and Eccles, 2003; Eisman et al., 2016; Linver et al., 2009), but this association differs according to sex, age, type of activity, and parental education level. As the previous literature shows, boys participate more in sports activities while girls do more in artistic activities (Darling, 2005; Kleiner et al., 2004; Luthar et al., 2006), and participation is higher in early adolescence than in late adolescence (Denault and Poulin, 2009b, 2009a; Rose-Krasnor et al., 2006).

Regarding the control variables in the prediction of academic achievement, the youngest girls have the highest grades, as has been found previously (Badura et al., 2016; OECD, 2015). On the other hand, a higher level of parental education is associated with higher academic achievement, in both early and late adolescence (Bartko and Eccles, 2003). The study by Roth et al. (2010) produces the same result, as well as an association with a smaller number of behavioral problems, but only when youths with high levels of participation were compared with peers who did not
Table 3 Comparison of means for levels of factors evaluated of the multilevel model for each age group with extracurricular activities (EA) as the dependent variable.

\begin{tabular}{llll} 
Factor & Levels & $\begin{array}{l}\text { 12-14 y.o. } \\
\text { Mean (S.D.) }\end{array}$ & $\begin{array}{c}\text { 15-18 y.o. } \\
\text { Mean (S.D.) }\end{array}$ \\
\hline Sex & Boy & $4.87(0.25) b^{\star}$ & $3.87(0.30) \mathrm{a}$ \\
& Girl & $5.32(0.24) \mathrm{a}$ & $4.12(0.29) \mathrm{a}$ \\
Parental & Low & $4.79(0.27) \mathrm{b}$ & $3.60(0.33) \mathrm{b}$ \\
education level & Middle & $5.06(0.25) \mathrm{a}$ & $4.05(0.30) \mathrm{a}$ \\
& High & $5.43(0.25) \mathrm{a}$ & $4.34(0.30) \mathrm{a}$ \\
Individual sports & No & $5.03(0.18) \mathrm{a}$ & $4.34(0.21) \mathrm{a}$ \\
activities & Yes & $5.16(0.34) \mathrm{a}$ & $3.66(0.42) \mathrm{a}$ \\
Collective sports & No & $5.03(0.19) \mathrm{a}$ & $4.55(0.22) \mathrm{a}$ \\
activities & Yes & $5.16(0.33) \mathrm{a}$ & $3.45(0.41) \mathrm{b}$ \\
Artistic activities & No & $5.12(0.17) \mathrm{a}$ & $4.28(0.21) \mathrm{a}$ \\
& Yes & $5.07(0.35) \mathrm{a}$ & $3.71(0.43) \mathrm{a}$ \\
Reading books & No & $4.77(0.16) \mathrm{b}$ & $4.15(0.18) \mathrm{a}$ \\
& Yes & $5.42(0.35) \mathrm{a}$ & $3.85(0.44) \mathrm{a}$ \\
Breadth of EA & Low & $4.87(0.48) \mathrm{a}$ & $2.99(0.59) \mathrm{b}$ \\
& Middle & $5.06(0.29) \mathrm{a}$ & $4.18(0.35) \mathrm{a}$ \\
& High & $5.35(0.18) \mathrm{a}$ & $4.82(0.21) \mathrm{a}$ \\
Duration of EA & Low & $4.58(0.26) \mathrm{c}$ & $3.87(0.30) \mathrm{a}$ \\
& Middle & $5.02(0.26) \mathrm{b}$ & $3.91(0.34) \mathrm{a}$ \\
& High & $5.68(0.26) \mathrm{a}$ & $4.22(0.31) \mathrm{a}$ \\
\hline
\end{tabular}

attend EA. Kingdon et al. (2017) found that reading and involvement of mothers are protective factors against the decrease in academic achievement in boys, as well as a predictor of future achievements, especially among low-income groups.

Addressing the first hypothesis (i.e., type of activity is associated with academic achievement), academic achievement relates negatively with collective sport EA in late adolescence. This is in line with the previous literature where sports activities relate to lower academic achievement than other types of EA, such as artistic activities (Badura et al., 2016; Darling, 2005; Darling et al., 2005; Eccles et al., 2003; Hansen et al., 2010; Wilson et al., 2010). However, this relationship was not significant in the study by Im et al. (2016). Linver et al. (2009) showed that students who participated only in sports EA had more positive results in academic achievement than those with little or no participation in organized activities, but worse academic achievement than those who participate in sports plus other activities, such as school, community, or religious groups.

We did not obtain a significant association between artistic EA and academic achievement, contrary to the results obtained in other studies, where artistic activities, not sports, provide greater reinforcement for academic achievement (Im et al., 2016), but only in girls (Luthar et al., 2006) or in late adolescents (Eccles et al., 2003).

Moreover, our work confirms the results of previous research by finding an association between reading books and academic achievement in early adolescence, namely, schoolchildren between 12 and 14 years old, the same age segment that Kingdon et al. (2017) reports. However, unlike our results, other research has found the same relation in late adolescence (e.g. Horbec, 2012; Whitten et al., 2019).

Regarding the second and third hypotheses (duration and breadth are associated with academic achievement), our results are in line with previous research, in which breadth (Fredricks, 2012; Fredricks and Eccles, 2006; Linver et al., 2009; Mahoney et al., 2006) and Duration (Darling, 2005; Darling et al., 2005; Eccles et al., 2003; Fredricks and Eccles, 2006; Zaff et al., 2003) 


\section{$12-14$ years old}

a

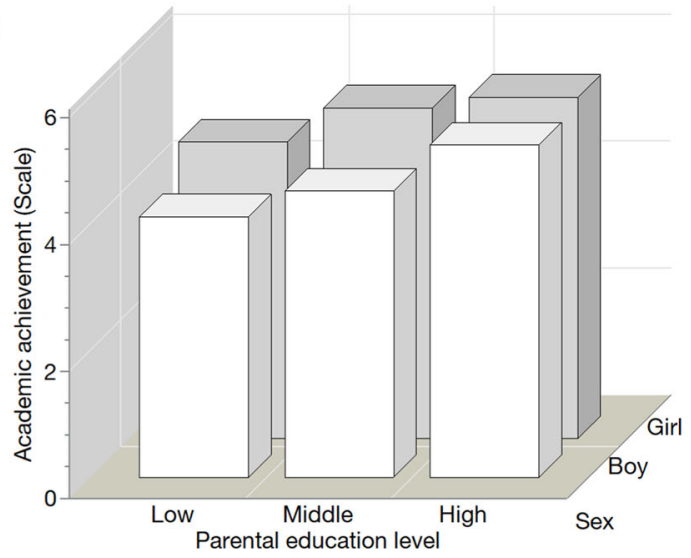

b

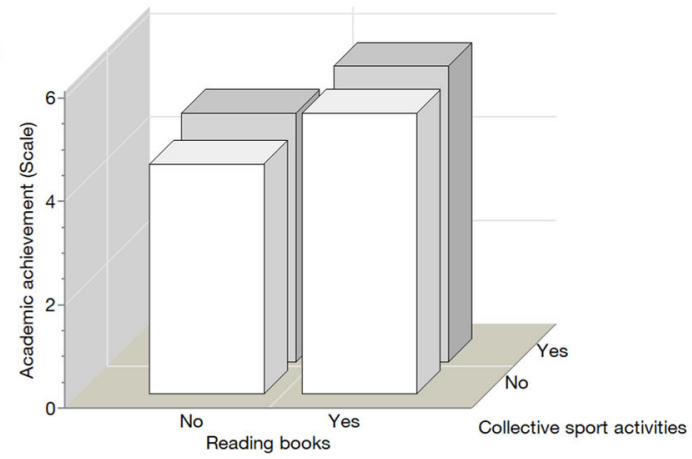

C

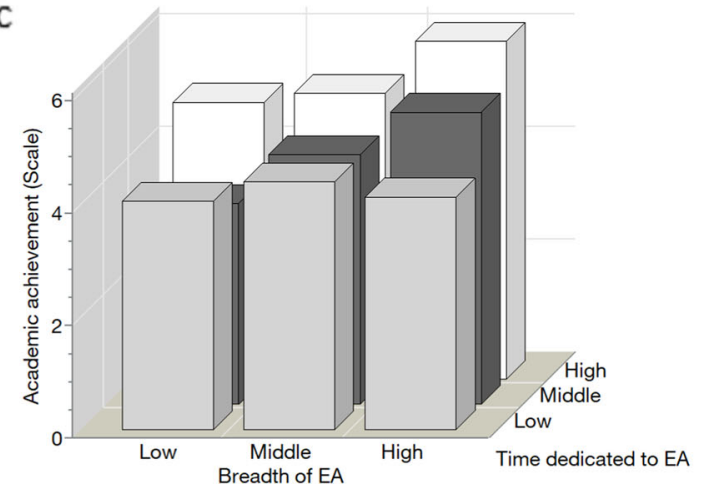

$15-16$ years old
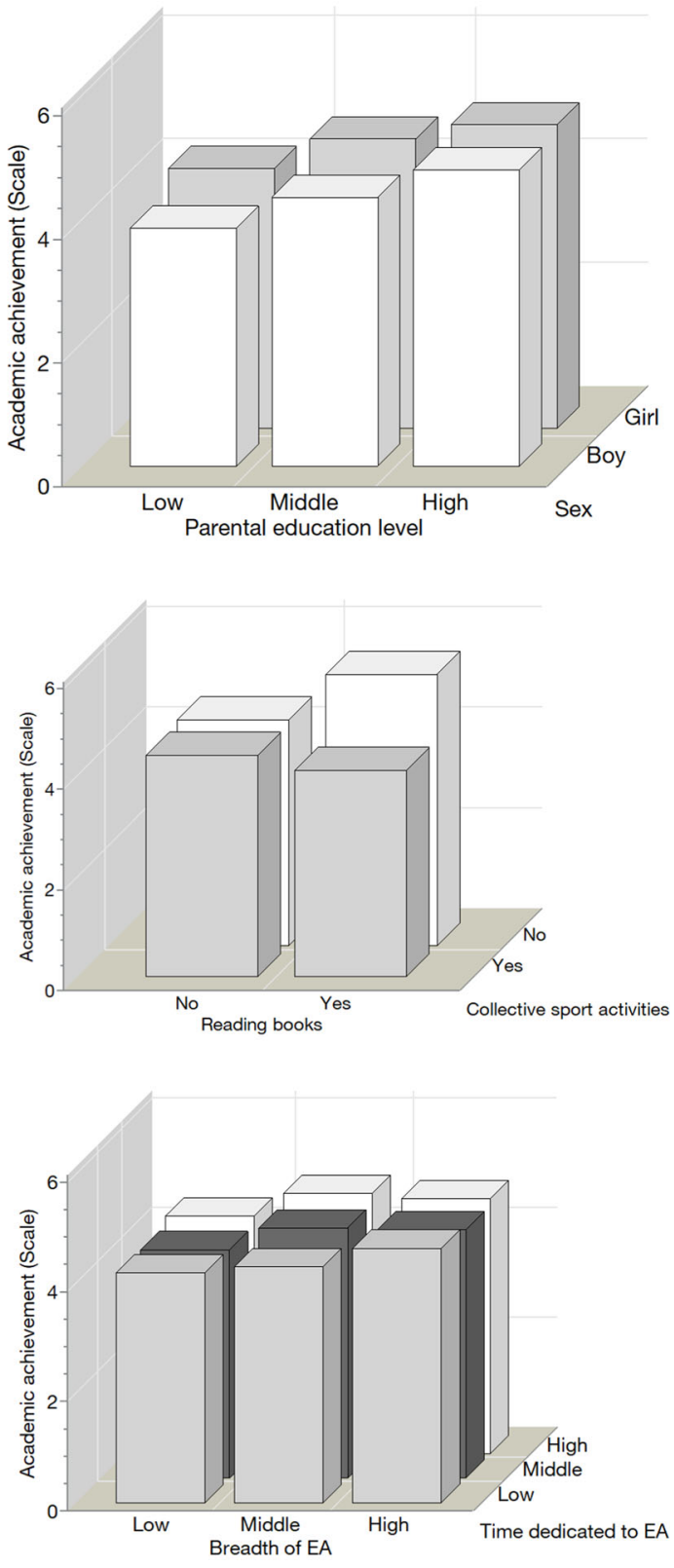

Fig. 1 Means of academic achievement grouped by age sets, predictors, and confusing factors. a Sex and parental education level; $\mathbf{b}$ breadth and duration of EA; and $\mathbf{c}$ collective sports activity and reading of books.

relate to improvement of academic achievement. Nevertheless, our results show that duration is better predictor than breadth, contrary to previous literature (Barber et al., 2005; Eisman et al., 2016; Fredricks and Eccles, 2006).

However, we found that duration of EA is a predictor of academic achievement only in early adolescence, as Roth et al. (2010) and Eisman et al. (2016) show. On the other hand, in late adolescence, breadth is an important factor that enhances academic achievement as Eisman et al. (2016) show, but contrary to the results of Roth et al. (2010). Our findings confirm the evolutionary hypothesis that Eisman et al. (2016) present. In this sense, the stage of development of the young person would indicate the importance of the type of engagement (behavioral or psychological). Thus, in early adolescence, breadth would be more important, as those young people are more likely to seek a wide range of EA participation experiences (Busseri and Rose-Krasnor, 2009), to test which are more deserving of the investment of their free time. Thus, in late adolescence, they have already acquired greater control over time itself (Fredricks and Eccles, 2010), allowing more intense on specific activities and reducing the range of breadth (Busseri et al., 2006; Denault and Poulin, 2009b).

While the literature reports that participating in EA has a positive relationship with academic achievement, this is only true to a certain extent, since too long a duration has a negative impact (Fredricks, 2012; Fredricks and Eccles, 2010; Palma et al., 2014). Indeed, the overprogramming hypothesis (OSH) suggests a point at which the resulting participation becomes counterproductive in terms of benefits to the young person (Fredricks and Eccles, 2010; Mahoney et al., 2006). An explanation for this could be that much time invested in EA interferes with time that could be devoted to 
the family, curricular tasks, or other moments that the young person needs (Fredricks and Eccles, 2010; Mahoney and Vest, 2012; Palma et al., 2014), regardless of whether this occurs in early, middle, or late adolescence.

After all, the positive effects of participation in EA are manifest. Mahoney et al. (2005) reveal that participation in activitiesvoluntary, school and extracurricular-increases participation and school achievement because it facilitates the acquisition of interpersonal skills and positive social norms, membership in prosocial peer groups, and strengthening of emotional and social connections with the school itself.

Both the curricular and extracurricular schedules can trigger differential benefits in young people, nourishing the student in a beneficial way throughout adolescent development, through the interrelation of both contexts.

Limitations and future directions. According to Eisman et al. (2016), limitations of research on participation in EA and association with academic achievement may include a selection bias toward adolescents who start high school with higher levels of selfacceptance. They are more likely to participate (or be selected) in organized activities due to the high levels of skill required to participate, together with higher academic achievement.

Another limitation is that data on the intensity of participation have not been collected. It would be interesting to check in future studies how differences in intensity of participation over time relate to academic achievement by determining the proportion of time when participation occurs, as Vandell et al. (2015) shows. In any case, the main limitations of the investigation are the instrument used is a self-report and that it is a cross-sectional study, so longitudinal studies are required to make a causal explanation possible.

In fact, it should be added that the quantitative design prevents drawing broader conclusions. A multi-method design are more consistent and would enrich the information around the students' perceptions, especially regarding the reasons why the activities are chosen. And, in this sense, would also deepen into the reasons why these activities are not chosen, as well as whether the offer suit all groups of adolescents.

An additional limitation is that no more complex models were evaluated (i.e., models with interactions). However, an attempt to correct that limitation included doing independent analyses for each of the age groups, but other factors can interact, such as sex with the other variables. But for statistical robustness, we do not consider that model. A longitudinal study that asks about behavior in recent years could try to correct that bias.

Besides, future research should also be directed to investigate the level of participation of students in these activitiesperformance, persistence, concentration, autonomy, etc.-and its relationship with their characteristics as students and their academic and social success in school.

In addition, this model is proposed for students with a common academic background. Therefore, students whose academic trajectories were not in the courses of the ordinary curricular approach were taken out of the study. We refer to students enrolled in curricular diversification or alternative curricular proposals for being unable to follow the ordinary academic trajectory.

\section{Data availability}

The datasets analyzed during the current study are available on the following repository link: https://zenodo.org/record/ 3689261\#.XlgI32hKiUk

\section{Code availability}

The code is the following: EDI FEB 122020.
Received: 22 March 2020; Accepted: 12 August 2020;

Published online: 01 September 2020

\section{References}

Badura P, Sigmund E, Geckova AM, Sigmundova D, Sirucek J, Van Dijk JP, Reijneveld SA (2016) Is participation in organized leisure-time activities associated with school performance in adolescence? PLoS ONE 11(4). https:// doi.org/10.1371/journal.pone.0153276

Barber BL, Stone MR, Eccles JS (2005) Adolescent participation in organized activities. In: Moore KA, Lippman LH (Eds) What do children need to flourish? Conceptualizing and measuring indicators of positive development. Springer, Boston, pp. 133-146

Bartko WT, Eccles JS (2003) Adolescent participation in structured and unstructured activities: a person-oriented analysis. J Youth Adolesc 32(4):233-241. https://doi.org/10.1023/A:1023056425648

Bohnert A, Fredricks J, Randall E (2010) Capturing unique dimensions of youth organized activity involvement: theoretical and methodological considerations. Rev Educ Res 80(4):576-610. https://doi.org/10.3102/0034654310364533

British Educational Research Association (2011) Ethical guidelines for educational research. BERA, London

Busseri MA, Rose-Krasnor L (2009) Breadth and intensity: Salient, separable, and developmentally significant dimensions of structured youth activity involvement. Br J Dev Psychol 27(4):907-933. https://doi.org/10.1348/026151008X397017

Busseri MA, Rose-Krasnor L, Willoughby T, Chalmers H (2006) A longitudinal examination of breadth and intensity of youth activity involvement and successful development. Dev Psychol 42(6):1313-1326. https://doi.org/ 10.1037/0012-1649.42.6.1313

Darling N (2005) Participation in extracurricular activities and adolescent adjustment: cross-sectional and longitudinal findings. J Youth Adolesc. 34 (5):493-505. https://doi.org/10.1007/s10964-005-7266-8

Darling N, Caldwell LL, Smith R (2005) Participation in school-based extracurricular activities and adolescent adjustment. J Leisure Res 37(1):51-76. https://doi.org/10.1080/00222216.2005.11950040

Denault AS, Poulin F (2009a) Intensity and breadth of participation in organized activities during the adolescent years: multiple associations with youth outcomes. J Youth Adolesc. 38(9):1199-1213. https://doi.org/10.1007/s10964-009-9437-5

Denault AS, Poulin F (2009b) Predictors of adolescent participation in organized activities: a five-year longitudinal study. J Res Adolesc 19(2):287-311. https:// doi.org/10.1111/j.1532-7795.2009.00597.x

Durlak JA, Mahoney JL, Bohnert AM, Parente ME (2010) Developing and improving after-school programs to enhance youth's personal growth and adjustment: a special issue of AJCP. Am J Community Psychol 45 (3-4):285-293. https://doi.org/10.1007/s10464-010-9298-9

Eccles JS, Barber BL (1999) Student council, volunteering, basketball, or marching band: what kind of extracurricular involvement matters? J Adolesc Res 14 (1):10-43. https://doi.org/10.1177/0743558499141003

Eccles JS, Barber BL, Stone M, Hunt J (2003) Extracurricular activities and adolescent development. J Soc Issues 59(4):865-889. https://doi.org/10.1046/ j.0022-4537.2003.00095.x

Eccles JS, Gootman JA (2002) Community programs to promote youth development. https://doi.org/10.17226/10022

Eccles JS, Templeton J (2002) Extracurricular and other after-school activities for youth. Rev Res Educ 26(1):113-180

Eisman AB, Stoddard SA, Bauermeister JA, Caldwell CH, Zimmerman MA (2016) Trajectories of organized activity participation among urban adolescents: an analysis of predisposing factors. J Youth Adolesc 45(1):225-238. https://doi org/10.1007/s10964-015-0267-3

Farb AF, Matjasko JL (2012) Recent advances in research on school-based extracurricular activities and adolescent development. Dev Rev 32(1):1-48. https:// doi.org/10.1016/j.dr.2011.10.001

Feldman AF, Matjasko JL (2007) Profiles and portfolios of adolescent school-based extracurricular activity participation. J Adolesc 30(2):313-332. https://doi. org/10.1016/j.adolescence.2006.03.004

Fredricks JA (2012) Extracurricular participation and academic outcomes: testing the over-scheduling hypothesis. J Youth Adolesc 41(3):295-306. https://doi. org/10.1007/s10964-011-9704-0

Fredricks JA, Eccles JS (2006) Extracurricular involvement and adolescent adjustment: Impact of duration, number of activities, and breadth of participation. Appl Dev Sci 10(3):132-146. https://doi.org/10.1207/s1532480xads1003_3

Fredricks JA, Eccles JS (2010) Breadth of extracurricular participation and adolescent adjustment among African-American and European-American Youth. J Res Adolesc 20(2):307-333. https://doi.org/10.1111/j.15327795.2009.00627.x

Hansen DM, Larson RW (2007) Amplifiers of developmental and negative experiences in organized activities: dosage, motivation, lead roles, and adult- 
youth ratios. J Appl Dev Psychol 28(4):360-374. https://doi.org/10.1016/j. appdev.2007.04.006

Hansen DM, Larson RW, Dworkin JB (2003) What adolescents learn in organized youth activities: a survey of self-reported developmental experiences. J Res Adolesc 13(1):25-55. https://doi.org/10.1111/1532-7795.1301006

Hansen DM, Skorupski WP, Arrington TL (2010) Differences in developmental experiences for commonly used categories of organized youth activities. J Appl Dev Psychol 31(6):413-421. https://doi.org/10.1016/j.appdev.2010.07.001

Hermoso Y, García V, Chinchilla JL (2010) Estudio de la ocupación del tiempo libre de los escolares Study of the participation of schoolchildren in leisure time Retos 18:9-13. http://www.redalyc.org/articulo.oa?id=345732284002

Hirsch BJ, Deutsch NL, DuBois DL (2011) After-school centers and youth development: case studies of success and failure. Cambridge University Press, New York

Horbec D (2012) The link between reading and academic success. English in Australia $\quad 47(2): 58 . \quad$ https://search.informit.com.au/documentSummary; $\mathrm{dn}=739383174235983$; res $=$ IELAPA

Im MH, Hughes JN, Cao Q, Kwok OM (2016) Effects of extracurricular participation during middle school on academic motivation and achievement at Grade 9. Am Educ Res J 53(5):1343-1375. https://doi.org/10.3102/ 0002831216667479

Kingdon D, Serbin LA, Stack DM (2017) Understanding the gender gap in school performance among low-income children: a developmental trajectory analysis. Int J Behav Dev 41(2):265-274. https://doi.org/10.1177/0165025416631836

Kleiner B, Nolin MJ, Chapman C (2004) Before- and after-programs, and activities children in kindergarten through eighth grade: 2001. Education. https://files. eric.ed.gov/fulltext/ED483065.pdf

Larson RW, Hansen DM, Moneta G (2006) Differing profiles of developmental experiences across types of organized youth activities. Dev Psychol 42 (5):849-863. https://doi.org/10.1037/0012-1649.42.5.849

Linver MR, Roth JL, Brooks-Gunn J (2009) Patterns of adolescents' participation in organized activities: are sports best when combined with other activities? Dev Psychol 45(2):354-367. https://doi.org/10.1037/a0014133

Luthar SS, Shoum KA, Brown PJ (2006) Extracurricular involvement among affluent youth: a scapegoat for "Ubiquitous Achievement Pressures"? Dev Psychol 42(3):583-597. https://doi.org/10.1007/s11145-010-9260-0.How

Mahoney JL (2000) School extracurricular activity participation as a moderator in the development of antisocial patterns. Child Dev 71(2):502-516. https://doi. org/10.1111/1467-8624.00160

Mahoney JL, Cairns BD, Farmer TW (2003) Promoting interpersonal competence and educational success through extracurricular activity participation. J Educ Psychol 95(2):409-418. https://doi.org/10.1037/0022-0663.95.2.409

Mahoney JL, Harris AL, Eccles JS (2006) Organized activity participation, positive youth development, and the over-scheduling hypothesis. Soc Policy Rep 20 (4):1-32. https://doi.org/10.1002/j.2379-3988.2006.tb00049.x

Mahoney JL, Larson, RW, Eccles JS (2005) Organized activities as contexts of development: extracurricular activities, after school and community programs. Psychology Press

Mahoney JL, Vest AE (2012) The over-scheduling hypothesis revisited: intensity of organized activity participation during adolescence and young adult outcomes. J Res Adolesc 22(3):409-418. https://doi.org/10.1111/j.1532-7795.2012.00808.x

McGaha V, Fitzpatrick J (2010) Employment, academic and extracurricular contributors to college aspirations J College Admiss 207:22-29. https://acces.bibl. ulaval.ca/login?url= https://search.ebscohost.com/login.aspx?direct=true\&db= eue\&AN $=508156558 \&$ lang $=$ fr\&site $=$ ehost-liv

Mueller MK, Lewin-Bizan S, Urban JB (2011) Youth activity involvement and positive youth development. Adv Child Dev Behav 41:231-249. https://doi. org/10.1016/B978-0-12-386492-5.00009-9

National Institute of Child Health and Human Development Early Child Care Research Network (2004) Are child developmental outcomes related to before- and after-school care arrangements? Results from the NICHD Study of Early Child Care. Child Dev 75(1):280-295. https://doi.org/10.1111/j.14678624.2004.00669.x

OECD (2015) The ABC of gender equality in education: aptitude, behaviour, confidence. OECD

Palma JR, Van Boekel M, Stanke L, Vue K, Cabrera JC, Chang Y, ... Bulut O (2014) Examining after school activities: do breadth and intensity matter? Annual meeting of the American Educational Research Association. pp. 1-12. https:// conservancy.umn.edu/bitstream/handle/11299/194905/2014-BreadthIntensityAERA.pdf?sequence $=1$

Peck SC, Roesner RW, Zarrett N, Eccles JS (2008) Erratum: "Exploring the roles of extracurricular activity quantity and quality in the educational resilience of vulnerable adolescents: variable- and pattern-centered approaches". J Soc Issues 64(1):430. https://doi.org/10.1111/j.1540-4560.2008.00570.x

Pedersen S (2005) Urban adolescents' out-of-school activity profiles: associations with youth, family, and school transition characteristics. Appl Dev Sci 9 (2):107-124. https://doi.org/10.1207/s1532480xads0902_5
Pierce KM, Auger A, Vandell DL (2013) Associations between structured activity participation and academic outcomes in middle childhood: narrowing the achievement gap. Biennial meeting of the Society for Research in Child Development, Seattle, WA

Pierce KM, Bolt DM, Vandell DL (2010) Specific features of after-school program quality: associations with children's functioning in middle childhood. Am J Community Psychol 45(3-4):381-393. https://doi.org/10.1007/s10464-0109304-2

Quinn J (1999) Where need meets opportunity: youth development programs for early teens. Future Children 9(2):96-116. https://doi.org/10.2307/1602709

Rose-Krasnor L, Busseri MA, Willoughby T, Chalmers H (2006) Breadth and intensity of youth activity involvement as contexts for positive development. J Youth Adolesc 35(3):365-379. https://doi.org/10.1007/s10964-006-9037-6

Roth JL, Brooks-Gunn J, Murray L, Foster W (1998) Promoting healthy adolescents: synthesis of youth development program evaluations. J Res Adolesc 8 (4):423-459. https://doi.org/10.1207/s15327795jra0804_2

Roth JL, Malone LM, Brooks-Gunn J (2010) Does the amount of participation in afterschool programs relate to developmental outcomes? A review of the literature. Am J Community Psychol 45(3-4):310-324. https://doi.org/ 10.1007/s10464-010-9303-3

Rubin J (2008) Judging our students-keeping it just: the theorem of intellectual measure. J College Admiss 199:4-11

Simpkins SD, Little PMD, Weiss HB, Simpkins-Chaput S (2004) Understanding and measuring attendance in out-of-school programs. Issues and opportunities in out-of-school time evaluation briefs. p. 7

Tudge JRH, Mokrova I, Hatfield BE, Karnik RB (2009) Uses and misuses of Bronfenbrenner's bioecological theory of human development. J Fam Theory \& Rev 1:198-210. https://doi.org/10.1111/j.1756-2589.2009.00026.x

Urban JB, Lewin-Bizan S, Lerner RM (2009) The role of neighborhood ecological assets and activity involvement in youth developmental outcomes: differential impacts of asset poor and asset rich neighborhoods. J Appl Dev Psychol 30 (5):601-614. https://doi.org/10.1016/j.appdev.2009.07.003

Vandell DL, Larson RW, Mahoney JL, Watts TW (2015) Children's organized activities. In: Bornstein MH, Leventhal T, Lerner R (Eds) Handbook of child psychology and developmental science. Wiley, New York, pp. 1-40

Weiss HB, Little PMD, Bouffard SM (2005) More than just being there: balancing the participation equation. New Dir Youth Dev (105):15-31. https://doi.org/ 10.1002/yd.105

Whitten C, Labby S, Sullivan SL (2019) The impact of pleasure reading on academic success. J Multidiscip Grad Res 2(1):48-64

Wilson DM, Gottfredson DC, Cross AB, Rorie M, Connell N (2010) Youth development in after-school leisure activities. J Early Adolesc 30(5):668-690. https://doi.org/10.1177/0272431609341048

Zaff JF, Moore KA, Papillo AR, Williams S (2003) Implications of extracurricular activity participation during adolescence on positive outcomes. J Adolesc Res 18(6):599-630. https://doi.org/10.1177/0743558403254779

\section{Competing interests}

The authors declare no competing interests.

\section{Additional information}

Correspondence and requests for materials should be addressed to A.B.

Reprints and permission information is available at http://www.nature.com/reprints

Publisher's note Springer Nature remains neutral with regard to jurisdictional claims in published maps and institutional affiliations.

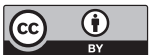

Open Access This article is licensed under a Creative Commons Attribution 4.0 International License, which permits use, sharing, adaptation, distribution and reproduction in any medium or format, as long as you give appropriate credit to the original author(s) and the source, provide a link to the Creative Commons license, and indicate if changes were made. The images or other third party material in this article are included in the article's Creative Commons license, unles indicated otherwise in a credit line to the material. If material is not included in the article's Creative Commons license and your intended use is not permitted by statutory regulation or exceeds the permitted use, you will need to obtain permission directly from the copyright holder. To view a copy of this license, visit http://creativecommons.org/ licenses/by/4.0/.

(c) The Author(s) 2020 